\title{
Analisis Desain Kebijakan Alokasi Bantuan Dana Kelurahan Tahun 2019
}

\author{
Monica Faradila ${ }^{1}$, Achmad Lutfi $i^{2}$ \\ ${ }^{1}$ Departemen Ilmu Administrasi Negara, Fakultas Ilmu Administrasi, Universitas Indonesia, Indonesia. \\ ${ }^{2}$ Departemen Ilmu Administrasi Negara, Fakultas Ilmu Administrasi, Universitas Indonesia, Indonesia.
}

\section{ARTICLE INFORMATION}

Received: March 02, 2020

Revised: October 26, 2020

Accepted: October 28, 2020

Available online: November 11, 2020

\section{KEYWORDS}

Regional Financial Allocation, Policy Design, Village Fund

\section{CORRESPONDENCE}

E-mail: monica.faradila@ui.ac.id

\author{
A B S T R A C T
}

This study discusses the analysis of the design of the Urban Village Funds policy in 2019. Urban Village Funds is a form of transfer of funds from the Central Government to the Regional Government to support the infrastructure development and the empowerment of the Urban Village community. The research method used in this study is through a postpositivist approach to the type of descriptive research and data collection techniques through in-depth interviews and literature studies. The theory used in this research is the Policy Design theory by Birkland (2011) which divides into five elements of policy design. The results of this study show that the design of the Urban Village Funds policy is inappropriate. This can be seen from the three elements, one of which can be said to be incompatible with the design of the Urban Village Funds policy. As a new transfer allocation, the Urban Village Funds policy does not have its nomenclature, so it uses the Additional DAU scheme. The use of the nomenclature is judged to be incompatible with the specific characteristics of the Urban Village Funds policy and does not have a clear calculation formulation

\section{PENDAHULUAN}

Keberadaan kebijakan desentralisasi membawa konsekuensi adanya otonomi daerah. Dalam perkembangannya, perjalanan penerapan desentalisasi di Indonesia ibarat "bandul jam" yang bergerak pada satu titik pendulum yang memusat (sentripetal) kepada titik pendulum yang menyebar atau disebut pola sentrifugal (Adi, 2019; Prasojo et al., 2006). Hal ini dapat dilihat dari sisi regulasi mengenai desentralisasi yang telah beberapa kali dibenahi hingga revisi terakhir yang berlaku yaitu UU Pemerintahan Daerah No. 23 Tahun 2014.

Adanya beberapa kali perubahan secara normatif dalam mengatur pelaksanaan pemerintahan daerah dapat berdampak pada sejumlah perubahan bagi jajaran pemerintahan yang ada di daerah. Salah satu yang mengalami perubahan adalah Kelurahan. Hal tersebut dapat dilihat dari perubahan kedudukan Kelurahan yang mengalami perubahan dalam UU Pemerintahan Daerah (Keuangan, 2018; Prasetyo et al., 2017). Apabila melihat UU Pemerintahan Daerah sebelumnya, kedudukan kelurahan sebagai perangkat kecamatan memang telah disebutkan pada Undang-Undang Nomor 22 Tahun 1999. Namun, setelah dilakukan revisi dan melahirkan UndangUndang Nomor 32 Tahun 2004, kedudukan kelurahan diperluas menjadi bagian dari perangkat Kabupaten/Kota (Putera, 2018; Sholeh et al., 2019). Akan tetapi, kedudukan kelurahan harus kembali diubah menjadi bagian dari perangkat kecamatan sebagaimana tertuang dalam Undang-Undang No. 23 Tahun 2014.

Mengacu pada UU Pemerintahan Daerah No. 23 Tahun 2014, kedudukan kelurahan sebagai perangkat Kecamatan berdampak pada kewenangan kelurahan menjadi terbatas. Hal ini perlu menjadi perhatian pemerintah terhadap kelurahan mengingat letaknya khas berada di perkotaan. Seiring berkembangnya zaman, kompleksitas kehidupan perkotaan menjadi sebuah fenomena empirik yang krusial (Prasojo et al., 2006)Perkotaan sendiri masih menghadapi sejumlah persoalan mendasar yaitu: seperti peningkatan pertumbuhan penduduk, kemiskinan, kawasan kumuh, hingga kriminalitas. Kondisi tersebut juga tentunya akan berimplikasi pada kegiatan penyelenggaraan pemerintahan di Kelurahan. Disamping itu, muncul fenomena kelurahan yang ingin berubah statusnya menjadi desa. Alasan utama yang melatarbelakangi adalah keinginan untuk memiliki keleluasaan dalam menggunakan hak politiknya dalam mengatur wilayahnya sendiri (Mardhiah, 2017; Nurhanifa et al., 2019).

Maka dari itu, sebagai upaya mengatasi persoalan tersebut, dibutuhkan peran strategis dari Pemerintah melalui upayaupaya yang dilakukan secara responsif (Aminah \& Sari, 2018; Sidik et al., 2002). Hal ini disebabkan permasalahan di perkotaan akan berimplikasi pada aktivitas pemerintahan di Kelurahan. Salah satu upaya yang dilakukan Pemerintah yaitu memberikan skema baru dukungan pendanaan yang berasal dari APBN sebesar Rp3 triliun kepada 8.212 Kelurahan. Adapun kebijakan tersebut dikenal sebagai kebijakan Dana Kelurahan. Lebih lanjut, kebijakan Dana Kelurahan pada dasarnya adalah DAU Tambahan yang digunakan sebagai bagian dari alokasi bantuan dana bagi Kelurahan di Kab/Kota (Keuangan, 2018).

Namun demikian, dalam proses desain kebijakan Dana Kelurahan ini terdapat beberapa permasalahan, diantaranya masalah waktu pembuatan kebijakan yang terbilang singkat. Hal ini terlihat dari proses pembuatan kebijakan Dana Kelurahan yang memiliki waktu terbilang singkat. Pemerintah diharuskan untuk dapat menyelesaikan kebijakan ini agar dapat segera dicairkan pada awal tahun 2019. Padahal, usulan mengenai Dana Kelurahan ini baru disampaikan pertengahan 
bulan tepatnya setelah rapat antara Asosiasi Pemerintah Kota Indonesia (APEKSI) dengan Presiden di Istana Kepresidenan, Juli 2018 lalu (Putera, 2018). Selain itu, masalah penggunaan nomenklatur kebijakan Dana Kelurahan melalui skema DAU Tambahan dinilai tidak sama dan menyalahi konsep DAU sebagaimana yang dikemukakan Shah (2007) sebagai jenis transfer yang tidak memiliki tujuan dalam peruntukkannya. Kondisi tersebut membuat konsep alokasi kebijakan Dana Kelurahan yang dianggarkan melalui mekanisme DAU Tambahan menjadi abu-abu.

Kondisi waktu yang terbilang singkat berimplikasi juga pada proses pembuatan kebijakan Dana Kelurahan sehingga menjadi tidak optimal. Hal ini dapat dilihat dari sosialisasi terkait kebijakan Dana Kelurahan dari Pemerintah kepada Pemerintah Daerah belum secara menyeluruh dilakukan. Maka dari itu, kehadiran kebijakan Dana Kelurahan yang diharapkan menjadi dana stimulus bagi Kelurahan nyatanya belum dimanfaatkan secara optimal, hal ini terlihat dari realisasi kebijakan Dana Kelurahan pada kuartal I (Mei 2019) menujukkan angka sebesar $48,7 \%$ dari total pagu yang dianggarkan. Maka oleh karena itu, penting untuk memahami bagaimana analisis desain dari kebijakan Dana Kelurahan tahun 2019, karena akan berdampak pada efektivitas implementasi kebijakan kedepannya. Berdasarkan pemaparan tersebut, permasalahan yang diangkat dalam penelitian ini adalah "Bagaimana desain kebijakan Dana Kelurahan di tahun 2019?"

Terdapat beberapa landasan teori yang digunakan dalam penelitian ini diantaranya konsep policy design dan alokasi keuangan. Dalam beberapa literatur, konsep tersebut dikenal dengan policy design. (Peters, 2018) memberikan satu konsep sederhana yang menggambarkan "desain" dalam konteks pembuatan kebijakan sebagai sebuah proses dalam menciptakan respons kebijakan terhadap suatu masalah kebijakan. Pendapat lain dikemukakan oleh (Birkland, 2011) yang menyatakan policy design adalah sebuah proses merancang kebijakan baik melalui analisis teknis maupun proses politik untuk mencapai tujuan tertentu.

Dalam policy design terdapat lima elemen yang harus dipertimbangkan oleh pembuat kebijakan dalam mendesain suatu kebijakan. Lima elemen tersebut diilustrasikan pafa tabel 1 berikut:

Tabel 1. Elemen Policy Design

\section{Elements}

\begin{tabular}{ll}
\hline The goals of the policy & What are the goals of the policy? To eliminate a problem? To alleviate a problem but not \\
entirely eliminate it? & What is the causal model? Do we know that, if we do $X$, Y will result? How do we know \\
this? If we don't know, how can we find out? & What tools or instruments will be used to put the policy into effect? Will they be more or \\
The causal model & less coercive? \\
The tools of the policy & Choices predicated on our social construction of the target population? \\
The targets of the policy & How will the program be implemented? Who will lay out the implementation system?
\end{tabular}

Kelima elemen dari policy design tersebut adalah: 1) the goals of the policy, elemen ini mengartikan bahwa dalam membuat kebijakan perlu adanya pengidentifikasian tujuan yang jelas. Tentunya dalam proses pengidentifikasian tersebut tidak terlepas dari proses identifikasi masalah apa yang muncul; 2) the causal model, artinya pembuat kebijakan perlu memahami teori kausal yang melekat pada suatu kebijakan yang akan diimplementasikan; 3) the tools of the policy, artinya pembuat kebijakan memilih instrumen kebijakan yang digunakan sebagai cara untuk mengatasi masalah publik; 4) the targets of the policy, pemilihan target kebijakan yang jelas dari implementasi kebijakan ini; 5) the impementation of the policy, bagaimana rencana implementasi dari sebuah desain kebijakan. Hal ini penting karena pola instrumen akan menentukan tingkat diskresi yang tersedia bagi aktor-aktor yang terlibat.

Selain itu, konsep yang menjadi landasan teori dalam penelitian ini adalah konsep alokasi keuangan. Sejak dilaksanakannya otonomi daerah sebagai dampak dari adanya kebijakan desentralisasi membawa konsekuensi pada pemberian kewenangan dari pusat dan daerah dalam hal pengelolaan fiskal di daerah. Pengelolaan tersebut dimanifestasikan melalui salah satunya transfer dana dari pusat kepada daerah (hibah).

Dalam pelaksanaanya, transfer dana antarpemerintahan

76 Monica Faradila dan Achmad Lutfi memiliki berbagai instrumen/bentuk. Namun, besar dan jenis transfer dana yang diberikan tergantung pada konteksnya. Mengutip (Shah, 2007) yang mengklasifikasikan hibah kedalam dua kategori yaitu general-purpose transfers (atau disebut juga block grants) dan spesific-purpose purpose (dikenal spesific grants).

\section{METODE}

Dalam penyusunan metode penelitian, peneliti memperhatikan beberapa aspek yaitu pendekatan penelitian. Berkaitan dengan penelitian ini, pendekatan yang digunakan adalah pendekatan postpositivist. Menurut (Creswell, 2014) pendekatan postpositivist adalah pendekatan yang berangkat dari sebuah teori, kemudian peneliti melakukan kegiatan pengumpulan data guna mendukung/membantah teori dan melakukan perbaikan atas hasil terhadap penelitian berdasarkan hasil temuan.

Selain itu, ditinjau dari jenis penelitian, maka penelitian ini terbagi kedalam tiga klasifikasi yaitu: 1) jenis penelitian berdasarkan tujuan yakni penelitian deskriptif; 2) jenis penelitian berdasarkan manfaat yaitu penelitian murni; 3) jenis penelitian berdasarkan waktu yaitu penelitian cross-sectional yang dilaksanakan pada bulan Juni 2019 hingga Desember 2019. 
Selanjutnya, dalam melakukan pengumpulan data, teknik yang digunakan adalah teknik pengumpulan data kualitatif melalui wawancara mendalam dengan beberapa narasumber sebagai data primer dalam penelitian ini. Adapun narasumber dalam penelitian ini diantaranya Ditjen Perimbangan Keuangan Kementerian Keuangan, Ditjen Anggaran Kementerian Keuangan, Badan Kebijakan Fiskal Kementerian Keuangan, Ditjen Bina Administrasi Kewilayahan Kemendagri, APEKSI dan Akademisi. Selain itu, data sekunder yang digunakan dalam penelitian ini guna mendukung hasil analisis distudi kepustakaan.

\section{HASIL DAN PEMBAHASAN \\ The goals of the policy}

Elemen ini berkaitan dengan desain tujuan yang dimaksudkan untuk mengatasi masalah publik. Maka dari itu, dapat dikatakan bahwa pada elemen ini erat kaitannya dengan pendefinisian masalah dan penentuan tujuan suatu kebijakan. Dalam konteks kebijakan Dana Kelurahan, ada tiga tujuan dari adanya kebijakan Dana Kelurahan ini.

Pertama, keberadaan kebijakan ini bertujuan untuk mendorong penguatan anggaran bagi Kelurahan. Tentunya hal ini sejalan dengan apa yang diusulkan oleh para walikota yang tergabung dalam Asosiasi Pemeritah Kota Indonesia (APEKSI), yang pada saat itu menyampaikan perlunya pendanaan serupa seperti Dana Desa, khusus untuk kelurahan guna menjadi dana stimulus bagi perkembangan wilayah Kelurahan. Mengingat Kelurahan juga memiliki kompleksitas masalah yang sama dengan Desa. Ditjen Perimbangan Keuangan pada saat itu juga melakukan kajian dalam melihat kompleksitas permasalahan yang terjadi di Kelurahan, salah satunya masalah kemiskinan. Namun, demikian kajian yang dilakukan oleh Ditjen Perimbangan Keuangan tidak kompherensif dan pada dasarnya belum kuat dalam menjawab permasalahan yang sebenarnya terjadi di Kelurahan. Terlebih, pada prosesnya Ditjen Perimbangan Keuangan hanya mengandalkan data kemiskinan yang dikeluarkan oleh BPS untuk membandingkan tingkat penurunan kemiskinan yang terjadi di Desa dengan Kota. Proses identifikasi masalah yang dilakukan tidak cukup kuat dalam melihat permasalahan apa yang paling fundamental di lingkup Kelurahan.

Kedua, adanya kebijakan Dana Kelurahan yakni sebagai sebuah upaya baru dalam membangun keseimbangan antara Kelurahan dan Desa mengingat keduanya memiliki level yang sama. Terlebih sejak Dana Desa diimplementasikan pada 2015 lalu, perhatian Pemerintah Pusat seakan terfokus pada penguatan Desa (Karimah, Faizatul; Saleh, Kahirul; Wanusmawatie, 2017; PAKEH, 2018). Oleh karenanya, keberadaan Dana Kelurahan merupakan sebuah penyeimbang antara Kelurahan dan Desa yang dalam realitasnya dapat berhimpitan. Meskipun begitu, keseimbangan dalam pengertian ini tidak dapat disamakan. Hal ini dikarenakan, karakteristik lingkungan baik di Kelurahan dan Desa memiliki perbedaan yang cukup signifikan, kondisi tersebut yang membuat tingkat kebutuhan antara Kelurahan dengan Desa juga berbeda.

Ketiga, tujuan yang terakhir dari adanya kebijakan Dana Kelurahan ini adalah untuk mendorong Pemerintah Daerah dalam menjalankan kewajibannya untuk mengalokasikan anggaran kepada Kelurahan. Dari berbagai pertimbangan yang sudah dipaparkan sebelumnya, keberadaan kebijakan Dana
Kelurahan sebenarnya lebih menitikberatkan pada upaya mendorong anggaran APBD untuk Kelurahan. Hal ini disebabkan kewenangan dalam mengalokasikan anggaran untuk Kelurahan secara normatif berada ditangan Pemerintah Daerah. Amanat tersebut juga tertuang dalam Pasal 230 UU No. 23 Tahun 2014 tentang Pemerintah Daerah, kemudian diturunkan lagi kedalam Pasal 30 PP No. 17 Tahun 2018 tentang Kecamatan. Meskipun begitu, amanat tersebut tidak semua dijalankan oleh beberapa Daerah karena kapasitas fiskal yang terbatas. Namun demikian, apabila dicermati kembali, dalam peraturan perundang-undangan tersebut Pemerintah Pusat tidak memiliki kewajiban dalam mengalokasikan anggaran kepada Kelurahan. Maka sebagai kebijakan afirmatif yang disusun dalam rangka membantu Pemerintah Daerah dalam menjalankan amanat yang tertuang dalam peraturan perundang-undangan. Kata 'membantu atau menstimulus' menjadi kata kunci yang harus digaris bawahi, karena kata tersebut menunjukkan bahwa sebagai bentuk bantuan pendanaan, kebijakan Dana Kelurahan ini hanya bersifat sementara.

\section{The causal model of the policy}

Dalam konteks kebijakan Dana Kelurahan intevensi yang dilakukan Ditjen Perimbangan Keuangan dapat terlihat dari proses penyusunan peraturan teknis yang akan digunakan sebagai pedoman dalam melaksanakan kebijakan Dana Kelurahan. Intervensi yang dilakukan oleh Pemerintah Pusat dapat dikatakan tidak tepat, karena Pemerintah Pusat secara tidak langsung melaksanakan urusan yang sebenarnya merupakan urusan Pemerintah Daerah. Tentu hal tersebut menyalahi peraturan perundang-undangan.

Berbicara pengalokasian anggaran untuk Kelurahan pada dasarnya alokasi anggaran tersebut heavynya berada di tangan Pemerintah Daerah. Sedangkan, Pemerintah Pusat tidak memiliki kewajiban untuk menganggarkan kepada Kelurahan, terlebih melalui APBN. Hal ini apabila ditinjau secara struktur, Kelurahan merupakan bagian tak terpisahkan dari perangkat Kab/Kota yang berkedudukan di wilayah Kecamatan, maka dilihat dari sisi keuangan Kelurahan seharusnya sudah masuk didalam APBD. Sebagai bagian dari perangkat daerah, maka 'hitam putih' nya Kelurahan sangat bergantung pada Pemerintah Daerah. Lebih lanjut, 'hitam putih' yang dimaksud disini termasuk urusan perencanaan hingga pelaksanaan anggaran semua bergantung pada Pemerintah Daerah, karena sumber pendanaan utamanya berasal dari Pemerintah Daerah itu sendiri.

Selain itu, keberadaan kebijakan Dana Kelurahan juga tidak cukup kuat hanya dengan berlandaskan UU APBN. ini dikarenakan kekuatan UU APBN hanya kuat untuk tahun anggaran tersebut. Ditambah lagi, secara teori UU APBN merupakan Undang-Undang dalam arti formal yang hanya bersifat menetapkan bukan mengatur. Pergeseran paradigma tersebut perlu dibenahi kembali, sebab apabila UU APBN digunakan untuk mengatur hal-hal yang baru maka kondisi tersebut menandakan ada norma-norma baru. Konsekuensi yang dapat ditimbulkan dari kurang kuatnya kebijakan Dana Kelurahan ini secara hukum, maka keberadaannya pun juga tidak dapat terjamin untuk kedepannya dan implikasinya juga akan berpengaruh pada implementasi kebijakan yang tidak optimal. 


\section{The tools of the policy}

Dalam konteks kebijakan Dana Kelurahan yang karakteristik pendanaannya merupakan jenis transfer yang baru sehingga dalam UU Perimbangan Keuangan No. 33 Tahun 2004 dan Postur APBN juga belum ada, maka kebijakan Dana Kelurahan ini ditempatkan dalam Dana Alokasi Umum (DAU) Tambahan. Penempatan kebijakan Dana Kelurahan dalam DAU Tambahan bermula dari hasil Pembicaraan Pendahuluan antara Pemerintah dengan DPR. Pada intinya, kesimpulan dari pembicaraan pendahuluan tersebut disepakati bahwa Pemerintah harus mengalokasikan anggaran kepada Kelurahan melalui dana transfer umum.

Dalam pengelolaan keuangan daerah di Indonesia, dana transfer umum dibagi menjadi dua jenis transfer yakni DBH dan DAU. Namun demikian, Ditjen Perimbangan Keuangan menilai penempatan kebijakan Dana Kelurahan dalam dana transfer umum tidak tepat. Hal ini dikarenakan, karakteristik sharing revenue yang melekat pada Dana Bagi Hasil membuat penempatan kebijakan Dana Kelurahan di dalam skema ini dinilai tidak tepat. Apabila nomenklatur dari kebijakan Dana Kelurahan ini menggunakan skema DAU, penempatan tersebut tidak tepat. Secara konsep, DAU adalah salah satu jenis transfer dimana tidak ada ikatan dalam penggunaanya. Konsep tersebut tentunya bertentangan dengan karakteristik yang melekat pada kebijakan Dana Kelurahan yang lebih condong bersifat spesifik. Spesifik tersebut terlihat dari adanya dua prioritas penggunaan yang hanya diperuntukkan untuk pembangunan fisik dan pemberdayaan masyarakat di Kelurahan.

Dalam prosesnya, Ditjen Perimbangan Keuangan mempertimbangkan untuk menempatkan dalam DAK. Namun, penempatan dalam DAK akan menimbulkan ambiguitas karena apabila ditempatkan dalam DAK Fisik maka penggunaan yang sifatnya non fisik seperti pemberdayaan masyarakat Kelurahan menjadi tidak tepat. Sama halnya, apabila ditempatkan dalam DAK Non Fisik maka penggunaan yang bersifat fisik seperti pembangunan infrastruktur di Kelurahan menjadi tidak relevan. Maka kondisi waktu yang terbatas, Ditjen Perimbangan Keuangan menempatkan kebijakan Dana Kelurahan dalam skema DAU sebagai DAU Tambahan.

DAU menjadi pilihan karena karakteristiknya yang umum sehingga memungkinkan untuk mengakomodasi kebijakan yang tidak bisa ditempatkan di jenis transfer lainnya. Meskipun begitu, penempatan dalam DAU Tambahan juga merupakan tidak tepat dan Keberadaan kebijakan Dana Kelurahan dapat dikatakan sebagai salah bentuk kebijakan yang gagal karena apabila diidentifikasikan kembali, beberapa alternatif jenis dana transfer yang sudah dipaparkan sebelumnya juga tidak pas sebagai desain pengalokasian kebijakan Dana Kelurahan tahun 2019. Penempatan kebijakan Dana Kelurahan dalam DAU Tambahan juga sudah menyalahi konsep dari desain transfer Dana Alokasi Umum yang diserahkan sepenuhnya kepada Daerah. Namun sebaliknya, dalam kebijakan Dana Kelurahan tahun 2019 sendiri ditujukkan untuk penggunaan dibidang pembangunan fisik dan pemberdayaan masyarakat.

\section{The target of the policy}

Elemen berikutnya dari policy design adalah penentuan target kebijakan. Dalam konteks kebijakan Dana Kelurahan, dapat dikatakan terdapat dua target yang disasar dalam kebijakan ini.
Pertama, keberadaan kebijakan Dana Kelurahan ini ditujukan untuk pemerintahan Kelurahan agar dapat berdaya guna dan berperan besar dalam melaksanakan tugas dan fungsinya. Mengingat Kelurahan juga memiliki kompleksitas permasalahan seperti permasalahan kemiskinan di Perkotaan yang berdampak juga pada Kelurahan.

Kedua, adanya kebijakan Dana Kelurahan ini diharapkan dapat mendorong Pemerintah Daerah dalam menganggarkan APBD nya untuk Kelurahan. Kelurahan sebagai bagian dari perangkat daerah yang berada di wilayah Kecamatan menandakan bahwa tanggung jawab penyelenggaraan pemerintahan Kelurahan berada ditangan Pemerintah Daerah. Maka dengan adanya kebijakan Dana Kelurahan ini dapat menjadi sebuah stimulus dan juga menyadarkan Pemerintah Daerah untuk melaksanakan kewajibannya sebagaimana tertuang dalam UU No. 23 Tahun 2014 dan PP No. 17 Tahun 2018.

\section{The implementation of the policy}

Pada elemen ini dapat dikatakan, desian implementasi kebijakan Dana Kelurahan tahun 2019 tidak tepat. Hal ini juga sebagai konsekuensi dengan pemilihan instrumen kebijakan yang salah. Maka apabila diurai kembali konsep DAU Tambahan dalam konteks kebijakan Dana Kelurahan dengan konsep DAU pada umumnya memiliki perbedaan yang sangat signifikan. Perbedaan tersebut dapat ditinjau dari tiga aspek yakni pengalokasian, penyaluran dan penggunaan serta pelaporan dan pertanggungjawaban.

\section{Aspek Pengalokasian}

Aspek pertama yaitu pengalokasian. Desain implementasi ditinjau dari aspek ini dapat dikatakan memiliki perbedaan yang signifikan. Secara konsep, DAU (atau dikenal DAU Formula) merupakan salah satu jenis transfer pemerintah pusat kepada daerah bersifat block grants yang berarti tidak ada ketentuan terhadap penggunaan dari dana tersebut dan memiliki formulasi perhitungan tersendiri sebagaimana tercantum dalam UU Perimbangan Keuangan No. 33 Tahun 2004 (Shah, 2007; Sidik et.al, 2002).

Kondisi tersebut berbeda dengan DAU Tambahan dalam konteks kebijakan Dana Kelurahan. Hal ini dapat terlihat dari mekanisme pengalokasian dari DAU Tambahan tidak menggunakan formula atau rumus yang sudah ditetapkan dalam peraturan perundang-undangan, melainkan pengalokasian yang didasarkan pada jumlah Kelurahan disetiap daerah berdasarkan kategori pelayanan publik. Apabila dicermati kembali, mekanisme pengalokasian dari kebijakan Dana Kelurahan pada dasarnya memiliki besaran yang sama untuk setiap Kelurahan yang memiliki kategori sama. Kondisi demikian, membuat desain formulasi yang disusun oleh Ditjen Perimbangan Keuangan pada dasarnya tidak ada artinya. Terlebih lagi, desain formulasi tersebut tidak memiliki perhitungan yang jelas dari mana asalnya dan apa dasar pertimbangan yang dipilih. Hal ini dikarenakan apabila mengacu pada Lampiran PMK No. 187 Tahun 2018 tentang Tata Cara Penyaluran DAU Tambahan TA 2019, Pemerintah dalam hal ini Kementerian Keuangan dan Kementerian Dalam Negeri sudah menyajikan daftar daerah-daerah sesuai kategori layanan yang sudah diklasifikasikan.

Selain itu, desain dari formulasi DAU Tambahan juga tidak memperhatikan aspek jumlah penduduk. Hal ini terlihat perhitungan dengan melibatkan komponen jumlah kelurahan 
yang tersedia di setiap Kab/kota justru akan menimbulkan persoalan baru seperti gejolak antarkelurahan yang dikategorikan sama tetapi memiliki jumlah penduduk yang lebih sedikit. Implikasinya tentu kelurahan yang memiliki jumlah penduduk yang sedikit akan lebih merasakan manfaat dari adanya alokasi Dana Kelurahan atau DAU Tambahan ini.

\section{Aspek Penyaluran dan Penggunaan}

Pada aspek ini antara DAU dengan DAU Tambahan juga memiliki mekanisme yang berbeda. Hal ini terlihat dari mekanisme penyaluran dan penggunaan dari DAU Formula yang dilakukan setiap bulan dan penggunaannya pun diserahkan kepada daerah sesuai dengan prioritasnya masingmasing. Beda halnya dengan penyaluran DAU Tambahan yang dilakukan hanya dua kali dalam satu tahun anggaran. Tahapan tersebut terbagi menjadi dua yakni Tahap I sebesar 50\% (paling cepat Januari dan paling lambat Mei TA 2019) dan Tahap II sebesar 50\% (paling cepat Maret dan paling lambat Agustus TA 2019) dari pagu alokasi yang didapat. Ditambah lagi, setiap daerah juga harus memenuhi dua syarat utama apabila ingin mendapatkan alokasi DAU Tambahan ini, pemenuhan syarat yang harus dipenuhi oleh Pemerintah Daerah. Adanya persyaratan inilah yang menjadi pembeda dengan alokasi DAU Formula. Adapun dua syarat tersebut yaitu: 1) Peraturan Daerah mengenai APBD TA 2019; 2) surat pernyataan telah mengalokasikan anggaran untuk pendanaan Kelurahan dalam APBD TA 2019 sesuai dengan amanat UU Pemerintahan Daerah No. 23 Tahun 2014.

Desain penyaluran DAU Tambahan masih memiliki sejumlah kekurangan seperti pembuatan syarat yang tidak mempertimbangkan keberadaan peraturan teknis. Kondisi tersebut kemudian menjadi kendala bagi Pemda yang telah menetapkan APBD TA 2019 sehingga Pemerintah Daerah yang ingin mendapat alokasi DAU Tambahan ini perlu melakukan perubahan terhadap APBD. Lebih lanjut, adanya persyaratan dalam desain penyaluran DAU Tambahan sebenarnya juga sudah menyalahi konsep dari DAU itu sendiri. Hal tersebut kemudian menjadi dilematis karena sebagaimana yang dikemukakan Sidik et.al (2002) ada sejumlah faktor penting yang perlu diperhatikan dalam mendesain DAU, salah satunya kondisionalitas. Artinya, sebagai salah satu jenis transfer yang bersifat umum (unconditional block grants), maka desain sistem transfer dengan adanya persyaratan tertentu menjadi tidak relevan. Tentunya ini menjadi evaluasi bagi Pemerintah untuk menemukan nomenklatur yang tepat dalam mengakomodasi Dana Kelurahan selain menempatkan di DAU Tambahan.

Adapun mekanisme penggunaan dari DAU Tambahan ini berisikan rincian mengenai apa saja kegiatan yang dapat dilaksanakan oleh Kelurahan dengan menggunakan alokasi DAU Tambahan ini. Tentunya, rincian kegiatan tersebut juga tetap mengacu pada dua prioritas anggaran yang tertuang dalam Permendagri No. 130 Tahun 2018. Sebagai bagian dari perangkat Kecamatan, maka program-progam yang akan dilaksanakan dengan menggunakan dana yang berasal dari DAU Tambahan ini bergantung pada Camat. Hal ini dikarenakan program-program tersebut perlu disesuaikan dengan Renja dan Renstra Kecamatan.

\section{Aspek Pelaporan dan Pertanggungjawaban}

Sampai pada aspek terakhir antara DAU dengan DAU Tambahan memiliki mekanisme yang berbeda. Hal ini terlihat dari DAU Formula tidak ada mekanisme pelaporan dan pertanggungjawaban yang harus disampaikan Pemerintah Daerah kepada Ditjen Perimbangan Keuangan. Hal tersebut dikarenakan sifatnya yang umum sehingga dapat disesuaikan dengan kewenangan dan prioritas daerah. Berbeda dengan DAU Tambahan (Kebijakan Dana Kelurahan) yang memiliki mekanisme pelaporan dan pertanggungjawaban sendiri melalui Laporan Realisasi Penyerapan Dana Alokasi Umum Tambahan Tahap I, sebagaimana tercantum dalam Lampiran PMK No. 187 Tahun 2018 tentang Tata Cara Penyaluran DAU Tambahan TA 2019.

\section{KESIMPULAN}

Berdasarkan hasil penelitian mengenai formulasi Kebijakan Dana Kelurahan ditinjau dari perspektif policy design menujukkan bahwa desain kebijakan dari kebijakan ini dapat dikatakan tidak tepat. Dari lima elemen policy design hanya dua yang dinilai memiliki desain yang tepat. Elemen policy design yang dapat dikatakan sudah tepat yaitu the goals of the policy karena desain tujuan sudah jelas dimana tujuan tersebut ditekankan pada upaya membantu mengatasi permasalahan yang ada dilingkup Kelurahan, sebagai penyeimbang dengan Desa dan adanya kebijakan Dana Kelurahan ini juga didesain untuk membantu atau menstimulus Pemerintah Daerah dalam mengalokasikan mandatory spending nya kepada APBD. Elemen kedua yang sudah tepat adalah the target of the policy karena proses identifikasi target yang jelas dimana didesain untuk mendorong penguatan Kelurahan dan mendorong Pemerintah Daerah dalam mengalokasikan APBDnya kepada Kelurahan sesuai amanat peraturan perundang-undangan yang difokuskan untuk pembangunan fisik serta pemberdayaan masyarakat di Kelurahan. Maka kehadiran kebijakan Dana Kelurahan ditujukkan untuk mencapai dua sasaran agar mencapai hasil yang maksimal.

\section{REFERENSI}

Adi, Y. (2019). Bureaucratic Reform Barriers: A Case Study on the One Stop-Integrated Service Office in Bone Regency. JKAP (Jurnal Kebijakan Dan Administrasi Publik), 22(2), 146-154. https://doi.org/10.22146/jkap.34536

Aminah, A., \& Sari, N. (2018). Pengelolaan dan Pemanfaatan Dana Desa Untuk Pemberdayaan Masyarakat (Studi Kasus Di Gampong Gunong Meulinteung Kecamatan Panga Kabupaten Aceh Jaya). Jurnal Public Policy, 4(1). https://doi.org/10.35308/jpp.v4il.238

Birkland, T. A. (2011). An Introduction to the Policy Process: Theories, Concept, and Models of Public Policy Making. Routledge.

Creswell, J. W. (2014). Penelitian Kualitatif dan Desain Riset. Pustaka Pelajar.

Karimah, Faizatul ; Saleh, Kahirul ; Wanusmawatie, I. (2017). Pengelolaan Alokasi Dana Desa dalam Pemberdayaan Masyarakat. Jurnal Administrasi Publik (JAP), 2(4), 597-602.

Keuangan, K. (2018). Dana Kelurahan adalah Dana Alokasi Umum (DAU) Tambahan. Kementerian Keuangan.

Mardhiah, N. (2017). Identifikasi Tujuan dan Sasaran Pembangunan Desa Kabupaten Aceh Barat. Jurnal Public Policy, 3(1). https://doi.org/10.35308/jpp.v3il.753

Nurhanifa, D., Tjoetra, A., \& Ikhsan, I. (2019). PEMBERDAYAAN EKONOMI MASYARAKAT MELALUI DANA DESA: SEBUAH KEBIJAKAN PEMERINTAH 
ACEH BARAT. Jurnal Public Policy, 5(2), 108. https://doi.org/10.35308/jpp.v5i2.1122

PAKEH, A. (2018). Implementasi Kebijakan Alokasi Dana Gampong (ADG) dalam Meningkatkan Pembangunan di Kab. Aceh Barat. Jurnal Public Policy, 2(1). https://doi.org/10.35308/jpp.v2il.383

Peters, B. G. (2018). Policy Problem and Policy Design. Edward Elgar Publishing Limited.

Prasetyo, Z. N. D., Pabalik, D., \& Bintari, W. C. (2017). Implementasi Alokasi Dana Kelurahan Dalam Pemberdayaan Masyarakat Di Kelurahan Malawele Kabupaten Sorong. Gradual, 6(2), 42-53.

Prasojo, E., Maksum, I. R., \& Kurniawan, T. (2006). Desentralisasi \& Pemerintahan Daerah: Antara Model Demokrasi Lokal \& Efesiensi Struktural. DIA FISIP UI.

Putera, A. D. (2018). Ini Kronologi Adanya Dana Kelurahan. Kompas.

Shah, A. (2007). Intergovernmental Fiscal Transfers: Principles and Practices. In Robin Boadway \& Anwar Shah (Ed.). A Practitioner's Guide to Intergovernmental Fiscal Transfers. World Bank.

Sholeh, C., Sintaningrum, S., \& Sugandi, Y. S. (2019). Formulation of Innovation Policy: Case of Bandung Smart City. Jurnal Ilmu Sosial Dan Ilmu Politik, 22(3), 173. https://doi.org/10.22146/jsp.33698

Sidik, M., Raksaka B. Mahi, Robert Simanjuntak, \& Bambang Brodjonegoro. (2002). Dana Alokasi Umum - Konsep, Hambatan dan prospek di Era Otonomi Daerah. Kompas. 